\title{
Public expenditure composition and fiscal decentralization in Brazilian local governments: an analysis through unconditional quantile regression with longitudinal data
}

\author{
Kleber Morais de Sousa ${ }^{1}$ \\ Paulo Aguiar do Monte ${ }^{2}$ \\ 1 Universidade Federal Rural de Pernambuco / Unidade Acadêmica de Serra Talhada, Serra Talhada / PE - Brazil \\ 2 Universidade Federal da Paraíba / Departamento de Economia, João Pessoa / PB - Brazil
}

\begin{abstract}
This paper investigates the effect of increasing fiscal decentralization on the composition of public expenditures of Brazilian local governments. The research is innovative, demonstrating that the heterogeneity of expenditure scale influences the correlation between fiscal decentralization and public expenditure of local governments. The sample consisted of unbalanced panel data of 5,565 municipalities for 17 years from 2000 to 2016 . The analysis used unconditional quantile regression with panel data. The main findings were: (i) fiscal decentralization affects public expenditure in Brazilian local governments. However, this effect depends on local expenditure scale and fiscal decentralization strategy. For example, the median coefficient was negative in personnel expenditures, and the effect was positive for the third quartile of local governments, when fiscal decentralization was measured by the tax revenue over total revenue. On the other hand, the effects were also positive for median and third quartile regarding intergovernmental transfers per capita like proxy of fiscal decentralization; (ii) the measures (proxies) of fiscal decentralization are correlated with the composition of public expenditure; (iii) in median terms, fiscal decentralization has greater effects on investment expenditures than on current and personnel expenditures; and (iv) in median terms, the tax revenue participation promotes an increase in administrative and planning expenditures instead of expenditures in social functions. Fiscal decentralization measured by intergovernmental transfer per capita has more positive effects on social functions than on legislative and administrative functions. Keywords: fiscal decentralization; public expenditures; municipalities; local governments.
\end{abstract}

\section{Composição do gasto público e descentralização fiscal em governos locais brasileiros: uma análise por regressão quantílica incondicional com dados Iongitudinais}

Este artigo teve por objetivo investigar o efeito do aumento da descentralização fiscal na composição do gasto público dos governos locais brasileiros. A pesquisa inovou ao demonstrar que a heterogeneidade da escala do gasto influencia na correlação entre a descentralização fiscal e a composição do gasto público dos governos locais. A amostra foi composta por um painel de dados desbalanceado com 5.565 municípios durante 17 anos, correspondente ao período de 2000 a 2016. A análise foi realizada por meio da regressão quantílica incondicional. Os principais resultados foram: (i) a descentralização fiscal afeta nos gastos públicos dos governos locais brasileiros, contudo o tipo de efeito depende da escala do gasto local e da estratégia de descentralização fiscal. Por exemplo, nos gastos com pessoal, para a mediana, o coeficiente foi negativo e o efeito foi positivo para o terceiro quartil dos governos locais, quando a descentralização fiscal foi mensurada pela receita tributária sobre a receita total. Por outro lado, os efeitos foram também positivos para mediana e terceiro quartil considerando as transferências intergovernamentais per capita como proxy da descentralização fiscal; (ii) as mensurações (proxies) da descentralização fiscal são correlacionadas com a composição do gasto público; (iii) a descentralização fiscal afeta mais o gasto com investimentos que os gastos de pessoal e correntes em termos medianos; e (iv) em termos medianos, a participação da receita tributária promove o aumento do gasto em funções de administração e planejamento ao invés de gastos em funções sociais; por outro lado, a descentralização fiscal medida pelas transferências intergovernamentais per capita afeta positivamente mais funções sociais que funções legislativa e administrativa.

Palavras-chave: descentralização fiscal; gasto público; municípios; governos locais. 


\title{
Composición del gasto público y descentralización fiscal en los gobiernos locales brasileños: un análisis por regresión cuantílica incondicional con datos longitudinales
}

\begin{abstract}
Este artículo tuvo como objetivo investigar el efecto de una mayor descentralización fiscal en la composición del gasto público de los gobiernos locales brasileños. La investigación innovó al demostrar que la heterogeneidad de la escala del gasto influye en la correlación entre la descentralización fiscal y la composición del gasto público de los gobiernos locales. La muestra estuvo constituida por un panel de datos desbalanceados con 5.565 municipios durante 17 años, correspondientes al período 2000-2016. El análisis se realizó mediante regresión cuantílica incondicional. Los principales resultados fueron: (i) la descentralización fiscal afecta el gasto público de los gobiernos locales brasileños, sin embargo, el tipo de efecto depende de la escala del gasto local y de la estrategia de descentralización fiscal. Por ejemplo, en los gastos de personal, para la mediana, el coeficiente fue negativo y el efecto fue positivo para el tercer cuartil de los gobiernos locales, cuando la descentralización fiscal se midió por los ingresos tributarios sobre los ingresos totales. Por otro lado, los efectos también fueron positivos para la mediana y el tercer cuartil considerando las transferencias intergubernamentales per cápita como proxy de la descentralización fiscal; (ii) las medidas (proxies) de la descentralización fiscal se correlacionan con la composición del gasto público; (iii) la descentralización fiscal afecta más el gasto de inversión que los gastos de personal y los gastos corrientes en términos medianos; y (iv) en términos medianos, la participación de los ingresos tributarios promueve un aumento del gasto en funciones de gestión y planificación en lugar de gastos en funciones sociales; por otro lado, la descentralización fiscal medida por transferencias intergubernamentales per cápita afecta positivamente más funciones sociales que legislativas y administrativas.
\end{abstract}

Palabras clave: descentralización fiscal; gasto público; municipios; gobiernos locales.

\section{INTRODUCTION}

This paper focuses on the relation between the increase of fiscal decentralization and the composition of public expenditure in Brazilian municipalities. Fiscal decentralization is a mechanism to transfer power and fiscal responsibilities from the central government to the subnational governments (Oates, 1972). This process was adopted by many countries around the world, mainly in the 1980s (Weingast, 2014). In general, researches such as Alegre (2010), Arends (2017), Busemeyer (2008), Del Granado, Martinez-Vazquez and McNab (2018), Fiva (2006), Martinez-Vazquez, Lago-Peñas and Sacchi (2017), Sacchi and Salotti (2016), have indicated the effects of fiscal decentralization on the composition of public expenditure. However, these studies estimate the mean effects, which is not the most appropriate way to analyze this relation given the great heterogeneity among municipalities. Thus, the scale of expenditures is a good alternative to change the understanding on the effects of fiscal decentralization. Here, the scale of expenditure is understood as the amount of public expenditure accomplished by local governments, that is, the higher amount of expenditure the greater scale of the municipalities and they are likely to achieve better fiscal efficiency. If this is not considered in the analysis, the estimated average will tend to bias. The present paper innovates, then, by investigating the relation between fiscal decentralization and the public expenditures through unconditional quantile regression developed by Firpo, Fortin and Lemieux (2009).

Fiscal decentralization has been studied from different perspectives, especially in relation to governance, corruption and economic growth (Martinez-Vazquez et al., 2017). However, researches have indicated dissonant findings due to the diversity of fiscal decentralization settings used by different countries around the world. Theories on fiscal decentralization seem to be far from achieving consensus and maturity, for instance, in the differentiation from fiscal decentralization and public 
expenditures. Few studies have focused on the theme, such as the ones by Bénassy-Quéré, Gobalraja and Trannoy (2007) and Busemeyer (2008), who indicate that fiscal decentralization has positive effects on social and investment expenditures in local governments. On the other hand, the studies by Brennan and Buchanan (1980) showed that fiscal decentralization can promote negative increases in public expenditures. This is achieved mostly by incrementing administrative functions and workers, since bureaucrats form a potential interest group for political aspects, and mayors can capture it by financial resources. Despite the evidences, the most anticipated theoretical result is that public expenditures are better allocated with higher levels of fiscal decentralization, as municipalities have more information on the social needs of citizens (Hayer, 1945; Oates, 1972; Tiebout, 1976).

In Brazil, fiscal decentralization was implemented by the 1988 Federal Constitution, when municipalities were given the competence to create specific local taxes and assumed responsibilities to provide public services of primary healthcare and elementary education (Melo, Souza \& Bonfim, 2015). From 2000 to 2016, Brazilian municipalities had an actual rise in the average of $59.11 \%$ in intergovernmental transfers per capita from supranational governments. In other words, the capacity to provide public services by local government was reinforced in the last two decades.

Besides intergovernmental transfers, municipalities have increased their own tax collection. During the years from 2000 to 2016, the average participation of tax collection over total revenue increased from $4.5 \%$ to $7 \%$. Thus, there was an increase in both participation of public resources by transfers as well as by tax collection of municipalities. Nevertheless, few studies have been conducted to understand the behavior of public expenditures and the increase of financial resources in local Brazilian governments. For instance, Mendes (2005) observed that intergovernmental transfers are more susceptible to be allocated in the administrative and the legislative expenditures rather than in the local tax collection. Also, Araújo, Gonçalves and Machado (2017) indicated that the number of intergovernmental transfers accomplished by the National Health System (NHS) influences the destination of financial resources to the health sector by local Brazilian governments.

The analysis conducted used quantitative methods with data collected from FINBRA of the National Treasury Secretary (Secretaria do Tesouro Nacional [STN]) and Brazilian Statistics and Geography Institute (Instituto Brasileiro de Geografia e Estatística [IBGE]) datasets. The sample was composed of 5,565 Brazilian municipalities in an unbalanced panel for 17 years, during the period from 2000 to 2016. Data was treated with unconditional quantile regression developed by Firpo et al. (2009).

This paper is organized as follows: Introduction; section 2 focuses on the theoretical and empirical bases of the work; section 3 describes the investigation methods, variables and econometric model; section 4 presents findings and discussions; and finally, section 5 summarizes the conclusions of the work.

\section{FISCAL DECENTRALIZATION AND PUBLIC EXPENDITURE COMPOSITION}

Improving the population welfare through the allocation of public resources is the main strategy of local governments in the attempt to meet social needs - since the stabilization and the distribution of resources are better performed by central and regional governments (Musgrave, 1959). However, resources collected by local government are insufficient to maintain public services, notably in areas 
like education, health and social assistance (Bird, 2018). In this context, intergovernmental transfers are used to achieve fiscal balance and to ensure the standard services for local populations. The process called fiscal decentralization is a way to strengthen subnational governments either by tax collection or by intergovernmental transfers. In other words, fiscal decentralization is a mechanism to transfer power and fiscal responsibilities from central to subnational governments lest subnational governments have the conditions to perform your functions (Oates, 1972).

The assumption is that local governments are in better conditions of allocating resources for basic services. The argument is not new, it was first supported by Hayer (1945), followed by public finance authors such as Musgrave (1959), Oates (1972) and Tiebout (1976). Since then, fiscal decentralization has attracted the attention of researchers in investigations due to the effects on public administration regarding corruption and governance (Martinez-Vazquez et al., 2017) and the composition of public expenditures (Arends, 2017; Del Granado et al., 2018; Sacchi \& Salotti, 2016).

The effects of fiscal decentralization were observed by different ways on local expenditures. Some studies like Sakurai (2013) and Pansani, Serrano and Ferreira (2020) have been perceived the flypaper effects on Brazilian local governments. The flypaper effect was defined when "there is a significantly higher propensity for recipients [municipalities] to increase public expenditure in response to lumpsum inter-governmental grants than in response to equivalent increases in private income" by Oates (1985, p. 77). In other words, Brazilian local governments tend to increase expenditure instead of reducing tax revenue when more intergovernmental transfers are received.

Most researches about this topic claim that fiscal decentralization influences the composition of public expenditure. Martínez-Vázquez and McNab (2003) indicate that allocation of resources is best performed when public expenditures are accomplished by local governments rather than by the central government; with consequent economic growth. Rodríguez-Pose, Tijmstra and Bwire (2009) evidence that better allocation happens when current expenditures are changed to investment. Besides, Kappeler and Välilä (2008) identified an increase in productive public investment and a reduction of redistribution. Alegre (2010), in turn, studied whether fiscal decentralization was a crucial determinant for capital expenditure in the public budget of 17 Spanish regions from 1984 to 2003. In short, previous works indicate that the increase in investment expenditure has a positive effect on economic growth, whereas the increase in current expenditure is considered a negative influence.

However, the works of Kappeler and Välilä (2008) and Agénor (2011) also revealed that the effects of investment expenditure must be investigated with disaggregated classification because it can depend on the spending area, like infrastructure, health or education, thus promoting different results. In addition, the larger competition among subnational governments to attract companies and local residents can benefit the infrastructure expenditure (Grisorio \& Prota, 2015).

Fiscal decentralization has correlated positively with social expenditures from a functional composition perspective. Faguet (2004) observed that fiscal decentralization improved resource allocation according to the social needs by increasing public expenditure in human capital and social services in Bolivia. Del Granado et al. (2018) identified that decentralization increased the expenditure participation in areas like health and education in the total expenditure of 45 countries. Similarly, Busemeyer (2008) found positive correlations between fiscal decentralization and educational expenditure for countries in the Organization for Economic Co-operation and Development (OECD) from 1980 to 2001. 
Nevertheless, there are other items to consider in the analysis of public expenditure composition. For instance, Sacchi and Salotti (2016) argued that demographic changes are relevant in the composition of subnational expenditure. Concerning health services in particular, Mosca (2006) observed that demographic factors, such as social economic aspects, affect the cost of services and that the decentralization promoted greater health expenditures in 20 countries from the OECD. Furthermore, Cantarero and Pascual (2008) suggested the influence of fiscal decentralization on child mortality and life expectancy in the Spanish. Regarding social security, Fiva (2006) described larger fiscal autonomy in local governments of small-sized states, which consequently reduced intergovernmental transfers for the upkeep of social security in 18 OECD countries.

In Brazil, few works have focused on similar analyses. Mendes (2005) evidenced a capture of intergovernmental transfers by administrative and legislative expenditures, while Araújo et al. (2017) indicated that intergovernmental transfers from the National Health System (NHS) have direct influence on the volume of financial resources for the health sector in Brazilian local governments. In short, the increase in Brazilian fiscal decentralization demands further investigation in respect to local public expenditure, mainly after the 2000s - a gap that this paper tries to fill.

\section{METHODS, VARIABLES AND ECONOMETRIC MODEL}

Quantitative methods were employed in the analysis. The effects of fiscal decentralization on the components of public expenditure were estimated by Unconditional Quantile Regression (UQR) with longitudinal data (Firpo et al., 2009). UQR was chosen for the following reasons: i) it is a robust method for outlier treatment; ii) it allows the estimation of specific points of distribution that better represent the studied population; iii) the regression error component does not need to attend any specific distribution because the method is semiparametric; iv) the estimated coefficients can be interpreted unconditionally, similar to the Ordinary Least Square (OLS) method. Our analysis focused on the median, first and third quartiles because Brazilian municipalities have very different characteristics in respect to population, territory and economy that could bias the average.

According to Firpo et al. (2009) and the easy explanation of Killewald and Bearak (2014) work, UQR can be defined by equation 1 , as follows:

$$
R I F\left(Y ; q_{\tau}, F_{y}\right)=q_{\tau}+\left\{\left[\tau-1\left(Y \leq q_{\tau}\right)\right] / f_{Y}\left(q_{\tau}\right)\right\}
$$

Where $\mathrm{Y}$ is the outcome variable, $\tau$ is the quantile, $q_{\tau}$ is the value of $\mathrm{Y}$ at the $\tau$ th quantile, $f_{\mathrm{Y}}$ $\left(q_{\tau}\right)$ is the density of $\mathrm{Y}$ at $q_{\tau}, F_{y}$ is the cumulative distribution function of $\mathrm{Y}$ and 1 is the indicator function from which a dummy variable is created and set to 1 if the outcome variable is below the quantile analyzed. Standard errors are calculated using bootstrap because this technique considers the uncertainty of RIF estimations and uses clusters by municipality (Hubber-Sandwich) to control the model heteroscedasticity. In other words, errors were considered not-identically distributed (n.i.d.).

Briefly, the econometric model is described in equation 2, as follows:

$$
\ln \left(y_{i t}\right)=\beta_{0}+\beta_{1} \text { FiscalDec }_{i t}+\beta_{2} \text { Controle }+\beta_{3} \text { Região }_{i t}+\alpha_{i}+\varepsilon_{i t}
$$

Where, $y_{\mathrm{it}}$ is the local government expenditures according to its economic and functional classification: current expenditures, personnel expenditures, investment expenditures, legislative 
expenditures, planning and administrative expenditures, education expenditures, health expenditures, social assistance and social security expenditures in the municipalities $i$ and year $t$. Fiscaldec is the main variable in the research and it is measured by two proxies: tax revenue over total revenue (Guedes \& Gasparini, 2007; Thiessen, 2003) and intergovernmental transfers per capita for each municipality (Neyapti, 2013). The tax revenue over total revenue variable evidences how much the municipality exerts its fiscal autonomy due to fiscal decentralization. The intergovernmental transfers per capita variable reveals the fiscal decentralization achieved by transfers from central government to local governments, thus, there is a partial fiscal decentralization since the municipalities are less autonomous to collect and allocate these resources. Therefore, these variables were chosen in order to reveal different faces of fiscal decentralization.

The Control matrix was added to the model to allow variables that control the pressure for more public expenditures and better public services, according to Grisorio and Prota (2015), Jia, Guo and Zhang (2014) and Sacchi and Salotti (2016). The Control matrix was composed of economic, demographic and political variables described as follows: GDP is the gross domestic product; Younger is the population under 15 years of age; Elderly is the population over 65 years of age; and Electoral cycle is a dummy variable with value 1 when the municipality has election on the time $t$, otherwise, the value is 0 (Dias, Nossa \& Monte-Mor, 2018; Rogoff, 1990; Rogoff \& Sibert, 1988, Sakurai, 2009; Tufte, 1978; Videira \& Mattos, 2011).

Finally, Region is a matrix with dummy vectors that identifies the five Brazilian regions: South, Southeast, Midwest, North and Northeast. The dummy variable shows value 1 when the municipality is present in each region and value 0 otherwise. The Southeast is the comparison reference, hence their lack of dummy variables; $s$ are the coefficients estimated by UQR; are the individual fixed effects for municipality; and is the error term for entity $i$ in time $t$.

The data were collected from the FINBRA dataset in the National Treasury Secretary (NTS) and from the Census by the Brazilian Institute of Geography and Statistics (IBGE). The sample was formed by unbalanced longitudinal data from 5,565 municipalities from 2000 to 2016 (17 years) $(\mathrm{n}=5,565, \mathrm{~T}=1-17 ; \mathrm{N}=74,831)$.

\section{FINDINGS}

\subsection{An overview of fiscal decentralization in local governments}

Fiscal decentralization measured by tax revenue over total revenue and intergovernmental transfers per capita demonstrated great heterogeneity in Brazilian municipalities. Table 1 describes the statistical information regarding fiscal decentralization variables. The median of tax revenue over total revenue was 0.042 , while the first and third quartiles were almost half and double the median with 0.025 and 0.081 , respectively. Similar features were observed for the variable intergovernmental transfers per capita, the differences among first, median and third quartiles were very clear. Hence, the great disparity of fiscal decentralization in Brazilian local governments.

\section{TABLE 1 DESCRIPTIVE STATISTICS OF FISCAL DECENTRALIZATION FOR BRAZILIAN LOCAL}




\section{GOVERNMENTS FROM 2000-2016 - R\$ (REAL VALUES IN 2000)}

\begin{tabular}{|lccccc|}
\hline Variables & Minimum & $1^{\circ}$ quartile & Median & $3^{\circ}$ quartile & Maximum \\
\hline Tax revenue over total revenue (\%) & $3.0 e-5$ & 0.025 & 0.042 & 0.081 & 0.797 \\
\hline Intergov. transfers per capita (R\$) & 10.83 & 379.08 & 509.42 & 694.62 & $125,365.50$ \\
\hline
\end{tabular}

Note: The monetary values were deflated to the year 2000 by IGP-M from Fundação Getulio Vargas. Source: FINBRA and IBGE.

In addition, results from Table 1 reveal that tax collection has a small participation in the budget and that Brazilian municipalities are largely dependent on the financial resources from supranational governments.

Table 2 describes the two fiscal decentralization variables by Brazilian macro-regions. The variables local tax collection and intergovernmental transfers per capita kept growing from 2000 until 2014. After 2015, there is a small reduction probably due to an internal economic crisis in Brazil. Municipalities in the Northeast have the smallest percentage of tax collection and intergovernmental transfers per capita, while southern municipalities have the greatest percentage of tax collection. These results indicate great heterogeneity between municipalities and regions of the country.

\section{TABLE 2 DESCRIPTIVE STATISTICS OF FISCAL DECENTRALIZATION FOR BRAZILIAN LOCAL GOVERNMENTS BY MICROREGION FROM 2000-2016 - R\$ (REAL VALUES IN 2000)}

\begin{tabular}{|c|c|c|c|c|c|c|c|c|c|c|c|c|}
\hline \multirow{2}{*}{ Year } & \multicolumn{6}{|c|}{ Tax revenue over total revenue } & \multicolumn{6}{|c|}{ Intergovernmental transfers per capita } \\
\hline & $\mathrm{N}$ & NE & M & SE & S & Total & N & NE & M & SE & S & Total \\
\hline 2000 & 030 & 021 & 0.074 & 0.064 & 0.049 & 0.053 & 38.83 & 351 & 518.11 & 515.24 & 539.37 & 76.59 \\
\hline 2001 & .031 & 0.022 & 073 & 0.069 & 0.053 & .052 & $1,105.74$ & 353.69 & 514.52 & 517.01 & 552.93 & 513.28 \\
\hline 2002 & 0.043 & 0.032 & 0.078 & 0.067 & 0.066 & 0.058 & 360.22 & 334.94 & 446.59 & 473.23 & 514.47 & 419.52 \\
\hline 2003 & 0.041 & 0.032 & 0.080 & 0.070 & 0.071 & 0.060 & 009.04 & 323.51 & 433.46 & 493.84 & 503.12 & 415.82 \\
\hline 2004 & (017 & (1) & 0. & 0.07 & 0.065 & 0.0 & 36 & 310 & 445.15 & 50408 & 526.51 & 13207 \\
\hline 2005 & 0.044 & 0.035 & 0.079 & 0.073 & 0.066 & 0.061 & 442.57 & 407.03 & 527.23 & 571.62 & 605.75 & 501.04 \\
\hline 2006 & 0.048 & 0.031 & 0.076 & 0.072 & 0.067 & 0.060 & 475.19 & 441.38 & 580.99 & 614.61 & 633.09 & 540.59 \\
\hline 20 & 0 & 0.036 & 0 & 0.0 & 0. & 0.0 & 5 & 2 & 612 & 62 & 65 & 5 \\
\hline 2008 & 0.057 & 0.035 & 0.074 & 0.070 & 0.070 & 0.060 & 535.89 & 496.00 & 660.62 & 659.19 & 695.97 & 605.15 \\
\hline 2009 & 0.054 & 0. & 0. & 0.073 & 0.072 & 0.0 & 52 & 52 & 56 & 63 & 71 & be \\
\hline 2010 & 0 & 0.038 & 0.080 & 0.076 & 0.078 & 0.065 & 4 & 521 & 690.97 & 703.34 & 718.66 & 62660 \\
\hline 2011 & 0.059 & 0.037 & 0.080 & 0.077 & 0.079 & 0.065 & 788.56 & 604.07 & 742.55 & 780.92 & 787.74 & 71 \\
\hline
\end{tabular}




\begin{tabular}{|c|c|c|c|c|c|c|c|c|c|c|c|c|}
\hline \multirow{2}{*}{ Year } & \multicolumn{6}{|c|}{ Tax revenue over total revenue } & \multicolumn{6}{|c|}{ Intergovernmental transfers per capita } \\
\hline & $\mathrm{N}$ & $\mathrm{NE}$ & M & SE & $S$ & Total & $\mathrm{N}$ & $\mathrm{NE}$ & M & SE & $S$ & Total \\
\hline 2012 & 0.058 & 0.038 & 0.082 & 0.080 & 0.082 & 0.067 & 631.85 & 608.57 & 757.19 & 776.11 & 799.96 & 713.26 \\
\hline 2013 & 0.067 & 0.043 & 0.093 & 0.090 & 0.100 & 0.075 & 620.34 & 612.86 & 748.78 & 853.25 & 813.78 & 723.08 \\
\hline 2014 & 0.073 & 0.046 & 0.095 & 0.092 & 0.105 & 0.078 & 650.33 & 637.70 & 783.42 & 898.99 & 843.57 & 753.79 \\
\hline 2015 & 0.065 & 0.046 & 0.092 & 0.094 & 0.101 & 0.077 & 642.16 & 609.34 & 723.34 & 837.10 & 832.72 & 714.91 \\
\hline 2016 & 0.062 & 0.045 & 0.090 & 0.092 & 0.097 & 0.076 & 668.13 & 626.05 & 727.91 & 886.99 & 868.61 & 740.77 \\
\hline
\end{tabular}

Note: The monetary values were deflated to the year 2000 by IGP-M from Fundação Getulio Vargas. Source: FINBRA and IBGE.

\subsection{Local expenditures and the profile of Brazilian municipalities}

In the sequence, Table 3 shows the descriptive statistics of the main expenditure variables in the economic classification studied in this paper from 2000 to 2016. Brazilian municipalities have very distinct scales of local public expenditures. Similar to fiscal decentralization variables, there are great differences in each quartile for all three local public expenditures variables in the economic classification. Also, in terms of the median, investment expenditures are low (10.4\%) compared to current expenditures. In other words, the most part of local budgets is committed with current expenditures and mayors face limitations to improve the local infrastructure.

\section{TABLE 3 DESCRIPTIVE STATISTICS OF EXPENDITURES PER CAPITA BY ECONOMIC CLASSIFICATION FOR BRAZILIAN LOCAL GOVERNMENTS FROM 2000-2016 - R\$ (REAL VALUES IN 2000)}

\begin{tabular}{|c|c|c|c|c|c|}
\hline Economic classification & Minimum & $1^{\circ}$ quartile & Median & $3^{\circ}$ quartile & Maximum \\
\hline Current per capita & 23.02 & 406.74 & 551.90 & 748.98 & $112,369.40$ \\
\hline Personnel per capita & 1.97 & 205.44 & 293.66 & 402.63 & $37,567.40$ \\
\hline Investment per capita & 0.03 & 32.35 & 57.20 & 99.57 & $19,258.52$ \\
\hline
\end{tabular}

Note: The monetary values were deflated to the year 2000 by IGP-M from Fundação Getulio Vargas. Source: FINBRA and IBGE.

Graph 1 shows the distribution of local public expenditures by economic classification. The "a" part of Graph 1 shows the right asymmetric distribution of current expenditures, and the next two parts, "b" and "c", reveal similar features with lower levels of right asymmetric distribution. All chart variables were normalized by natural logarithm transformation. Based on the charts, it is possible to suggest that the average is biased to represent the behavior of the variables. Thus, the median and the quartiles can provide useful information on how fiscal decentralization works in different scales of local expenditures given the accentuated heterogeneity among municipalities. Analogous features 
were observed for functional expenditures (charts not shown due to limited space).

\section{GRAPH 1 HISTOGRAM OF LOCAL PUBLIC EXPENDITURE VARIABLES BY ECONOMIC CLASSIFICATION} FROM 2000-2016
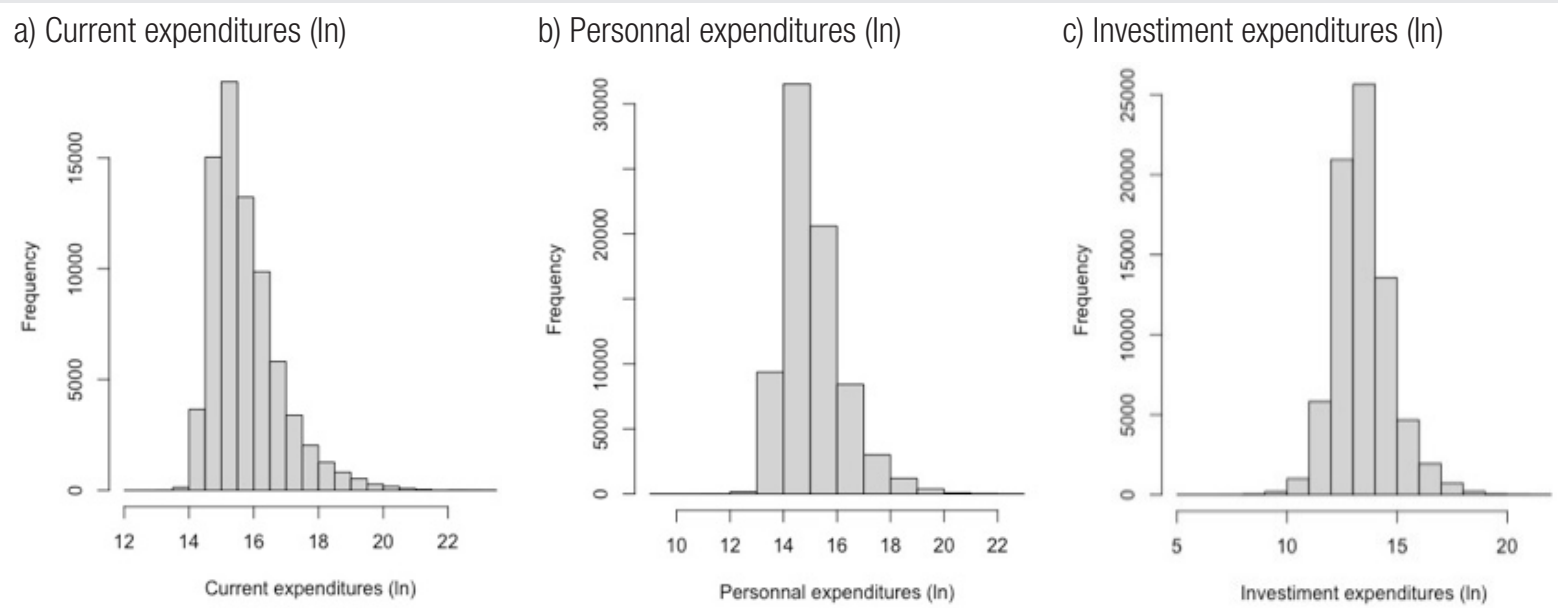

Note: In is natural logarithm.

Source: FINBRA and IBGE.

Functional classification also showed great heterogeneity. In median terms, legislative, planning and administrative expenditures are responsible for a great part of the local budgets and the many differences among municipalities are preserved. For instance, the first quartile of planning and administrative expenditures per capita is $\mathrm{R} \$ 49.93$ and the median is $\mathrm{R} \$ 92.51$, that is, $85.3 \%$ greater whereas the difference between the median and the third quartile is $93.1 \%(\mathrm{R} \$ 92.51$ and $\mathrm{R} \$ 178.61$, respectively). Similar features are observed for the other variables. Thus, in terms of functional classification, there is diversity in local expenditures.

\section{TABLE 4 DESCRIPTIVE STATISTICS OF EXPENDITURES PER CAPITA BY FUNCTIONAL CLASSIFICATION FOR BRAZILIAN LOCAL GOVERNMENTS FROM 2000-2016 - R\$ (REAL VALUES IN 2000)}

\begin{tabular}{lccccc}
\multicolumn{1}{c}{ Functional classification } & Minimum & $\mathbf{1}^{\circ}$ quartile & Median & $3^{\circ}$ quartile & Maximum \\
\hline Legislative per capita & 0.002 & 12.82 & 22.522 & 42.05 & $72,162.29$ \\
Planning and administrative per capita & 0.005 & 49.93 & 92.51 & 178.61 & $148,457.80$ \\
Culture and education per capita & 0.001 & 107.42 & 193.31 & 322.71 & $824,964.90$ \\
Health per capita & 0.033 & 70.73 & 140.48 & 258.69 & $772,590.80$ \\
Social assistance and social security per capita & 0.003 & 14.78 & 32.86 & 70.96 & $492,348.90$
\end{tabular}

Note: The monetary values were deflated to the year 2000 by IGP-M from Fundação Getulio Vargas. Source: FINBRA and IBGE.

Regarding the control variables, Brazilian municipalities displayed demographic and economic 
diversity. The descriptive statistics of GDP, Younger and Elderly variables are described in Table 5. In short, Brazilian local governments are diverse in terms of both economy and population.

\section{TABLE 5 DESCRIPTIVE STATISTICS OF CONTROL VARIABLES FOR BRAZILIAN LOCAL GOVERNMENTS FROM 2000-2016 - R\$ (REAL VALUES IN 2000)}

\begin{tabular}{lccccc}
\hline Variables & Minimum & $\mathbf{1}^{\circ}$ quartile & Median & $3^{\circ}$ quartile & Maximum \\
\hline GDP per capita (in Thousand) & 0.11 & 2.21 & 3.86 & 6.37 & 298.24 \\
Younger $(<15$ years) & 94 & 1,426 & 3,132 & 6,954 & $2,690,356$ \\
Elderly $(>64$ years) & 24 & 403 & 801 & 1,663 & $1,096,987$ \\
\hline
\end{tabular}

Note: The monetary values were deflated to the year 2000 by IGP-M from Fundação Getulio Vargas. Source: FINBRA and IBGE.

Treating these data with UQR for different positions of the distribution can provide good insights in this context, since the average, with great asymmetry and diversity, does not provide the best explanation for the phenomenon studied.

\subsection{Inferential findings}

The estimated regression coefficients for local expenditures by economic classification are described in the Table 6. All coefficients estimated by the econometric model used are presented in the Appendix of this paper. For current expenditures, the first quartile and the median showed negative effects of fiscal decentralization measured by tax revenue over total revenue, however, the effect was positive for the third quartile. The expected outcome for fiscal decentralization was confirmed for smaller municipalities when analyzed by tax revenue over total revenue. In other words, the higher tax revenue of a municipality, the smaller is the local expenditure due to citizens reject to towns with high level of taxes (Oates, 1972). On other hand, when fiscal decentralization is measured by intergovernmental transfers per capita, the effects are positive due to prevalence of flypaper effect.

In relation to personnel expenditures, the first quartile did not present statically significant results for both fiscal decentralization measurements. However, for the median of tax revenue over total revenue, the coefficient was negative, and the effect was positive for the third quartile. The effects were also positive for median and third quartile regarding intergovernmental transfers.

The analyses of investment expenditures and the measurements of fiscal decentralization were both statically insignificant in the first quartile, whereas the median and third quartile had statistically significant and positive effects for tax revenue over total revenue as well as for intergovernmental transfers per capita. 

CLASSIFICATION FOR BRAZILIAN LOCAL GOVERNMENTS FROM 2000-2016

\begin{tabular}{|c|c|c|c|c|c|c|}
\hline \multirow{3}{*}{ Dependent variable } & \multicolumn{6}{|c|}{ Independent variables } \\
\hline & \multicolumn{3}{|c|}{ Tax revenue over total revenue (\%) } & \multicolumn{3}{|c|}{ Intergov. transfers per capita (In) } \\
\hline & $=0.25$ & $=0.50$ & $=0.75$ & $=0.25$ & $=0.50$ & $=0.75$ \\
\hline Current expenditures(In) & $-1.02^{\star \star \star}$ & $-0.293^{\star \star \star}$ & $0.077^{\star \star \star}$ & $0.115^{\star \star \star}$ & $0.111^{\star \star \star}$ & $0.077^{\star \star \star}$ \\
\hline Personnel expenditures (In) & $-1.7 e-15$ & $-0.299^{* * *}$ & $0.243^{\star \star \star}$ & $7.66 \mathrm{e}-17$ & $0.178^{* * *}$ & $0.193^{\star \star \star}$ \\
\hline Investment expenditures (In) & $-5.7 e-15$ & $0.268^{\star \star \star}$ & $0.187^{\star \star \star}$ & $-9.5 e-15$ & $0.223^{\star \star \star}$ & $0.106^{\star \star \star}$ \\
\hline
\end{tabular}

Notes: ${ }^{*} \mathrm{p}<0,10 ;{ }^{* *} \mathrm{p}<0,05 ;{ }^{* * *} \mathrm{p}<0,01 ; \ln$ is the natural logarithm. $=0.25$ is the first quartile; $=0.50$ is the median; $=0.75$ is the third quartile. The estimated model was controlled by variables GDP, younger, elderly, electoral cycle, North, Northeast, Mideast and South that were omitted here (see Appendix to all coefficients).

Source: FINBRA and IBGE.

In relation to functional classification, the coefficients estimated for fiscal decentralization and quartiles are described in Table 7. Legislative expenditures, when fiscal decentralization is measured by tax revenue over total revenue, displayed positive significant and statistically effects just in the third quartile. On the other hand, when fiscal decentralization is measured by intergovernmental transfers per capita, the coefficients estimated for the median and the third quartile were statistically significant and positive. Similar results were observed for planning and administrative expenditures. For these types of expenditure, tax revenue over total revenue was statistically significant and positive for the median and the third quartile, while intergovernmental transfers per capita was statistically significant and positive for the median and for the third quartile.

The effects were different for functions like culture and education, health assistance and social security. Table 7 summarizes the estimated coefficients by functional classification of local expenditures (all coefficients estimated by the econometric model are presented in Appendix). In relation to expenditures on culture and education, tax revenue over total revenue showed statistically significant and negative effects for the median, and significant and positive effect for the third quartile. On the other hand, when fiscal decentralization was measured by intergovernmental transfers per capita, the effects were statistically positive for both median and third quartile. The same effects were observed for expenditures on health.

Finally, health assistance and social security expenditures showed statistically negative effects for the first quartile and the median as well as positive effects for the third quartile after estimations with tax revenue over total revenue. Regarding intergovernmental transfers per capita, the effects of fiscal decentralization were statistically negative for the first quartile and positive for the median and third quartile. Furthermore, the coefficients estimated for both fiscal decentralization variables were too small for the first quartile; in practical terms, they were irrelevant. 


\begin{tabular}{|c|c|c|c|c|c|c|}
\hline \multirow{3}{*}{$\begin{array}{l}\text { Dependent variable of expenditure } \\
\text { by functional classification }\end{array}$} & \multicolumn{6}{|c|}{ Independent variables } \\
\hline & \multicolumn{3}{|c|}{ Tax revenue over total revenue (\%) } & \multicolumn{3}{|c|}{ Intergov. transfers per capita (In) } \\
\hline & $=0.25$ & $=0.50$ & $=0.75$ & $=0.25$ & $=0.50$ & $=0.75$ \\
\hline Legislative (In) & $-5.2 e-15$ & -0.011 & $0.171^{\star \star \star}$ & $-3.9 e-15$ & $0.050^{\star \star \star}$ & $0.049^{\star \star \star}$ \\
\hline Planning and administrative (In) & $1.05 \mathrm{e}-14$ & $0.043^{\star \star \star}$ & $0.393^{\star \star \star}$ & $1.06 e-14$ & $0.084^{\star \star \star}$ & $0.058^{\star \star \star}$ \\
\hline Culture and education (In) & $-2.6 e-15$ & $-0.141^{\star \star \star}$ & $0.271^{\star \star \star}$ & $-8.0 e-15$ & $0.149^{\star \star \star}$ & $0.156^{\star \star \star}$ \\
\hline Health (In) & $9.12 \mathrm{e}-16$ & $-0.157^{\star \star \star}$ & $0.210^{\star \star \star}$ & $-6.6 e-15$ & $0.110^{\star \star \star}$ & $0.081^{\star \star \star}$ \\
\hline Assistance and social security (In) & $-3.5 e-15^{\star \star}$ & $-0.097^{\star \star \star}$ & $0.086^{\star \star \star}$ & $-1.0 e-14^{\star *}$ & $0.079^{* \star *}$ & $0.038^{\star \star \star}$ \\
\hline
\end{tabular}

Notes: ${ }^{*} \mathrm{p}<0,10 ;{ }^{* *} \mathrm{p}<0,05 ;{ }^{* *} \mathrm{p}<0,01 ; \ln$ is the natural logarithm. $=0.25$ is the first quartile; $=0.50$ is the median; $=0.75$ is the third quartile. The estimated model was controlled by variables GDP, younger, elderly, electoral cycle, North, Northeast, Mideast and South that were omitted here (see Appendix to all coefficients).

Source: FINBRA and IBGE.

To summarize, the effects of fiscal decentralization for the estimated coefficients were contingent on the position of the distribution. In other words, the effects of fiscal decentralization depend on the expenditure scale.

\section{DISCUSSION}

The fiscal decentralization studies indicate the local governments as more responsible for expenditures when financial resources come from their own tax collection because citizens pay more tax and, naturally, they feel motivated to analyze and to control the local public administration (Hayer, 1945; Oates, 1972; Tiebout, 1976). However, Brazilian local governments are heterogeneous, and the dynamic of public administration varies in smaller and larger municipalities, with possibly different effects of fiscal decentralization among them. Therefore, our findings are important because they help to identify the empirical evidences that confirm, albeit partially, the fiscal decentralization studies.

In relation to the economic classification of local public expenditures, the fiscal decentralization studies were confirmed for municipalities with lower levels of current and personnel expenditures. In median terms, the increase in tax revenue over total revenue was correlated with the decrease in current and personnel expenditures, while tax revenue over total revenue correlated positively with investment expenditures. Similar results were obtained for European countries by Kappeler and Välilä (2008). These results suggest that, when local governments are free to choose where to apply their resources, mayors are likely to choose investments that, in general, improve the infrastructure of cities (Rodríguez-Pose et al., 2009).

On the other hand, results were positive for all coefficients and types of expenditures in the third quartile. This indicates that the dynamic of municipalities with more elevated expenditures are different. This can happen for three main reasons: i) opportunistic behavior of mayors to increase job vacancies and attract support for their electoral campaign; ii) the "zoo" effect defined by Oates 
(1988), when larger municipalities have more complex services and, consequently, less efficiency; iii) the quality of the service provided by larger municipalities is higher than in smaller municipalities; iv) larger municipalities have big and complex structures of service provision and citizens can feel discouraged to control the public administration, unlike smaller municipalities. Thus, regarding the economic classification, the increase of tax revenue over total revenue is only good for the smaller municipalities located in the first part of the distribution.

The opposite was observed when fiscal decentralization was measured by intergovernmental transfers per capita, as statically significant and positive coefficients were observed for the three classifications under analysis. Such evidences reinforce the flypaper effect of intergovernmental transfers since local governments having received money from central or regional governments are more likely to commit the resources to specific expenditures. The financial laws in Brazil determine where, when, and how to apply, for instance, the grants and resources from special funding like education funding (FUNDEB) and the NHS funding (SUS). Therefore, fiscal decentralization by intergovernmental transfers reduces the freedom of local management to deal with specific financial demands and to choose the best allocation according to social needs.

In relation to the functional classification our results showed, in general, that local governments with middle activity, such as administrative, legislative and planning, were positively correlated with fiscal decentralization by both median and third quartile measurements. These findings make it possible to claim that fiscal decentralization is used opportunistically by local management. Besides, regarding the median, when we analyze fiscal decentralization by tax revenue over total revenue, reduced levels of social protection expenditure were noted whereas expenditure increased for administrative and planning functions, which disagrees with results by Faguet (2004). Therefore, these mayors spent resources from taxes on expenditures with less social impact as described by Fiva (2006) and Mendes (2005). On the other hand, for the third quartile, tax revenue over total revenue had positive effects for all functional classification, and larger municipalities seemed to present a different dynamic compared to smaller ones.

In regards to intergovernmental transfers, for the median and the third quartile, the effects were positive in all categories of expenditures; in general, the coefficients were higher for functions of social protection than for administrative and bureaucratic functions. Moreover, the results for functional expenditures once more confirm the flypaper effect, since intergovernmental transfers increased expenditures. The increase observed here for expenditures on education is in accordance with Busemeyer (2008) for OECD countries. There is an exception for the first quartile of the variable intergovernmental transfers per capita since the coefficient was statistically significant and negative. Nonetheless, the number is irrelevant in practical terms.

In short, the analysis reveals that legal rules and controls to apply intergovernmental transfers contribute to the destination of financial resources to social demands, conversely, tax revenue over total revenue reduces social expenditures. It is worth to highlight that the Brazilian results found here agree with Smith (2012) that observed local governments are relevant in process to promote public services in Mexico; and Grisorio and Prota (2015) which in turn demonstrated the fiscal decentralization influence on expenditure composition by economic and functional classification for Italian local governments. 
With respect to control variables, an interesting result was found for the electoral cycle. For current expenditures, the significant coefficients were negative, while personnel expenditures were positive mainly for investment expenditures. These findings confirm the opportunistic behavior of mayors in the electoral race. Considering the functional classification, in general, when electoral cycles were statistically significant, the coefficients were negative. This is probably due to the Fiscal Responsibility Law (FRL), which prohibits mayors from assuming, in the last eight months of their term in office, any expenditure commitment that may not be fully liquidated in their own term in office. It is interesting to observe, from this set of findings, that politicians can find ways to increase categories of expenditures, such as personal and investment, without adding to the main functional classification.

Another important aspect is the divergence between the regions of Brazilian municipalities. Most of the estimated models presented dummy variables with statistical significance, thus corroborating with Baskaran, Feld and Schnellenbach (2014). These results are a strong indication that heterogeneity correlates with the Brazilian regions as a consequence of culture and geographic features. The GDP and the populational variables were also significant in agreement with Grisorio and Prota (2015) and Sacchi and Salotti (2016).

Thus, the variables studied here, especially expenditure scales and types of fiscal decentralization should be considered during the decision make process in order to improve the fiscal efficiency of small and great municipalities. Furthermore, the quality of expenditure in relation to economic classification is improved when fiscal decentralization is accomplished by tax revenue on median size municipalities, while in relation to functional classification, the better effects to social expenditure happen when fiscal decentralization is achieved by intergovernmental transfers.

Finally, our findings indicate that the analysis of different positions of distribution by UQR provided good insights to better understand municipal heterogeneity and the effects of fiscal decentralization. Therefore, the results were relevant to identify that the effect of fiscal decentralization depends on expenditure scale and the existence of a huge heterogeneity. Although the great heterogeneity, it was possible pointed out some insights which can be used to improve the fiscal management on Brazilian local governments.

\section{CONCLUSIONS}

This work analyzed the effects of fiscal decentralization on the composition of public expenditure in Brazilian local governments for 17 years. The study faced methodological obstacles in the intrinsic heterogeneity of Brazilian municipalities. The findings confirmed the influence of fiscal decentralization on the composition of public expenditure of Brazilian local governments for economic and functional classifications, according to Arends (2017), Del Granado et al. (2018) and Sacchi and Salotti (2016) - even though the effects depended on the proxy fiscal decentralization, as indicated by Jia et al. (2014). On other hand, the research corroborates indications by Kappeler and Välilä (2008) and Rodríguez-Pose et al. (2009), who identified that fiscal decentralization reinforces investment expenditures. In addition, our work confirmed the need for further investigations on the heterogeneity of municipalities.

Concerning the functional composition, in median terms, the fiscal decentralization measured by tax revenue over total revenue promoted an increase in administrative and planning expenditures 
RAP | Public expenditure composition and fiscal decentralization in Brazilian local governments: an analysis through unconditional quantile regression with longitudinal data

as well as a decrease in social expenditures, in accordance with Mendes (2005). For the fiscal decentralization, measured by intergovernmental transfers per capita, social expenditures were prioritized, which confirmed the results by Del Granado et al. (2018).

Therefore, it is possible to conclude that studies about fiscal decentralization need to perform a detailed account of public expenditures, using distinct proxies of fiscal decentralization and considering the heterogeneity of local governments. Besides this, the budgetary earmarks of intergovernmental transfers can be explored especially in relation to educational and health areas and the division between conditional and unconditional financial resources on the local public expenditures by unconditional quantile regression in future researches. 


\section{REFERENCES}

Agénor, P. R. (2011). Schooling and public capital in a model of endogenous growth. Economica, 78(309), 108-132.

Alegre, J. G. (2010). Decentralization and the composition of public expenditure in Spain. Regional Studies, 44(8), 1067-1083.

Araújo, C. E. L., Gonçalves, G. Q., \& Machado, J. A. (2017). Os municípios brasileiros e os gastos próprios com saúde: algumas associações. Ciência \& Saúde Coletiva, 22(3), 953-963.

Arends, H. (2017). More with less? Fiscal decentralisation, public health spending and health sector performance. Swiss Political Science Review, 23(2), 144-174.

Baskaran, T., Feld, L. P., \& Schnellenbach, J. (2014, September). Fiscal federalism, decentralization and economic growth: Survey and meta-analysis (CESifo working paper No. 4985). Munich, Germany: CESifo.

Bénassy-Quéré, A., Gobalraja, N., \& Trannoy, A. (2007). Tax and public input competition. Economic Policy, 22(50), 386-430.

Bird, R. M. (2018). Fiscal decentralisation and decentralising tax administration: different questions, different answers. In A. Valdesalici, \& F. Palermo (Eds.), Comparing fiscal federalism (Studies in territorial and cultural diversity governance, Vol. 10, pp. 190-220). Leiden, The Netherlands: Brill Nijhoff.

Brennan, G., \& Buchanan, J. M. (1980). The power to tax: Analytic foundations of a fiscal constitution. Cambridge, UK: Cambridge University Press.

Busemeyer, M. R. (2008). The impact of fiscal decentralisation on education and other types of spending. Swiss Political Science Review, 14(3), $451-481$.

Cantarero, D., \& Pascual, M. (2008). Analysing the impact of fiscal decentralization on health outcomes: empirical evidence from Spain. Applied Economics Letters, 15(2), 109-111.

Del Granado, F. J. A., Martinez-Vazquez, J., \& McNab, R. M. (2018). Decentralized governance, expenditure composition, and preferences for public goods. Public Finance Review, 46(3), 359-388.
Dias, B. P., Nossa, V., \& Monte-Mor, D. S. (2018). O investimento público influencia na reeleição? Um estudo empírico nos municípios do estado do Espírito Santo. Revista de Administração Pública, 52(5), 880-898.

Faguet, J. P. (2004). Does decentralization increase government responsiveness to local needs? Evidence from Bolivia. Journal of public economics, 88(3-4), 867-893.

Firpo, S., Fortin, N. M., \& Lemieux, T. (2009). Unconditional quantile regressions. Econometrica, 77(3), 953-973.

Fiva, J. H. (2006). New evidence on the effect of fiscal decentralization on the size and composition of government spending. FinanzArchiv/Public Finance Analysis, 62(2), 250-280.

Grisorio, M. J., \& Prota, F. (2015). The impact of fiscal decentralization on the composition of public expenditure: panel data evidence from Italy. Regional Studies, 49(12), 1941-1956.

Guedes, K. P., \& Gasparini, C. E. (2007). Descentralização fiscal e tamanho do governo no Brasil. Economia Aplicada, 11(2), 303-323.

Hayek, F. A. (1945). The use of knowledge in society. The American economic review, 35(4), 519-530.

Jia, J., Guo, Q., \& Zhang, J. (2014, March). Fiscal decentralization and local expenditure policy in China. China Economic Review, 28, 107-122.

Kappeler, A., \& Välilä, T. (2008). Fiscal federalism and the composition of public investment in Europe. European Journal of Political Economy, 24(3), 562570.

Martinez-Vazquez, J., Lago-Peñas, S., \& Sacchi, A. (2017). The impact of fiscal decentralization: A survey. Journal of Economic Surveys, 31(4), 1095-1129.

Martinez-Vazquez, J., \& McNab, R. M. (2003). Fiscal decentralization and economic growth. World development, 31(9), 1597-1616.

Melo, C. A. V. D., Souza, S. S. D., \& Bonfim, W. L. D. S. (2015). Federalismo e bons governos: uma análise política da gestão fiscal dos municípios. Opinião Pública, 21(3), 673-692.

Mendes, M. (2005). Capture of fiscal transfers: a study of Brazilian local governments. Economia aplicada, 9(3), 427-444. 
Mosca, I. (2006). Is decentralisation the real solution? A three country study. Health policy, 77(1), 113-120.

Musgrave, R. A. (1959). Theory of public finance; a study in public economy. New York, NY: McGrawHill.

Neyapti, B. (2013). Fiscal decentralization, fiscal rules and fiscal discipline. Economics Letters, 121(3), 528-532.

Oates, W. E. (1972). Fiscal federalism. New York, NY: Harcourt Brace Jovanovich.

Oates, W. E. (1985). On the nature and measurement of fiscal illusion: a survey. In G. Brennan, B. S. Grewal, \& P. Groenewegen (Eds.), Taxation and fiscal federalism: essays in honour of Russell Mathews (pp. 65-82). Sydney, Australia: Australian National University Press.

Oates, W. E. (1988). On the measurement of congestion in the provision of local public goods. Journal of Urban Economics, 24(1), 85-94.

Pansani, D. A., Serrano, A. L. M., \& Ferreira, L. O. G. (2020). Análise de evidências e causas do efeito flypaper e da ilusão fiscal nos Estados e municípios brasileiros. Administração Pública e Gestão Social, 12(3), 1-19.

Rodríguez-Pose, A., Tijmstra, S. A., \& Bwire, A. (2009). Fiscal decentralisation, efficiency, and growth. Environment and Planning A, 41(9), 2041 2062.

Rogoff, K. (1990). Equilibrium political budget cycles. The American Economic, 80(1), 21-36.

Rogoff, K., \& Sibert, A. (1988). Elections and macroeconomic policy cycles. The review of economic studies, 55(1), 1-16.
Sacchi, A., \& Salotti, S. (2016). A comprehensive analysis of expenditure decentralization and of the composition of local public spending. Regional Studies, 50(1), 93-109.

Sakurai, S. N. (2009). Ciclos políticos nas funções orçamentárias dos municípios brasileiros: uma análise para o período 1990-2005 via dados em painel. Estudos Econômicos (São Paulo), 39(1), 39-58.

Sakurai, S. N. (2013). Efeitos assimétricos das Transferências Governamentais sobre os gastos públicos locais: evidências em painel para os municípios brasileiros. Pesquisa e Planejamento Econômico, 43(2), 309-332.

Smith, H. J. M. (2012). Fiscal decentralization and development: an analysis of city governments in Argentina and Mexico, 1980-2010 (Doctoral Dissertation). Florida International University, Miami, Florida.

Thiessen, U. (2003). Fiscal decentralisation and economic growth in high-income OECD Countries. Fiscal studies, 24(3), 237-274.

Tiebout, C. M. (1956). A pure theory of local expenditures. Journal of political economy, 64(5), 416-424.

Tufte, E. R. (1978). Political control of the economy. Princeton, NJ: Princeton University Press.

Videira, R. A., \& Mattos, E. (2011). Ciclos políticos eleitorais e a interação espacial de políticas fiscais entre os municípios brasileiros. Economia Aplicada, 15(2), 259-286.

Weingast, B. R. (2014, January). Second generation fiscal federalism: Political aspects of decentralization and economic development. World Development, $53,14-25$. 


\section{Kleber Morais de Sousa}

https://orcid.org/0000-0001-5362-9708

Ph.D. in Accounting Science from the Federal University of Paraíba (UFPB); Adjunct Professor at the Rural Federal University of Pernambuco/Academic Unit of Serra Talhada (UAST/UFRPE).

E-mail: kleber.sousa@ufrpe.br

\section{Paulo Aguiar do Monte}

https://orcid.org/0000-0001-5376-3771

Ph.D. in Economics from the Federal University of Pernambuco (UFPE); Associate Professor at the Federal University of Paraíba (UFPB). E-mail: pamonte@gmail.com 


\section{APPENDIX}

\section{TABLE A1 ESTIMATED EFFECTS OF FISCAL DECENTRALIZATION ON CURRENT EXPENDITURES FOR BRAZILIAN LOCAL GOVERNMENTS (2000-2016)}

\begin{tabular}{|c|c|c|c|c|c|c|}
\hline \multirow{3}{*}{ Variables } & \multicolumn{6}{|c|}{ Dependent variable: current expenditures } \\
\hline & \multicolumn{3}{|c|}{ Tax revenue over total revenue (\%) } & \multicolumn{3}{|c|}{ Intergov. transfers per capita (In) } \\
\hline & $=0.25$ & $=0.50$ & $=0.75$ & $=0.25$ & $=0.50$ & $=0.75$ \\
\hline Fiscal decentralization & $-1.020^{\star \star \star}$ & $-0.293^{\star \star \star}$ & $0.077^{\star \star \star}$ & $0.115^{\star \star \star}$ & $0.111^{\star \star \star}$ & $0.077^{\star \star \star}$ \\
\hline GDP (In) & $0.202^{\star \star \star}$ & $0.107^{\star \star \star}$ & $0.044^{\star \star \star}$ & $0.129^{\star \star \star}$ & $0.057^{\star \star \star}$ & $0.018^{\star \star \star}$ \\
\hline Younger (In) & $-0.067^{\star \star \star}$ & $0.027^{\star \star \star}$ & $0.005^{\star \star \star}$ & $0.007^{\star \star}$ & $0.094^{\star \star \star}$ & $0.050^{\star \star \star}$ \\
\hline Elderly (In) & $0.174^{\star \star \star}$ & $0.046^{\star \star \star}$ & $0.017^{\star \star \star}$ & $0.177^{\star \star \star}$ & $0.051^{\star \star \star}$ & $0.022^{\star \star \star}$ \\
\hline Electoral cycle (dummy) & $-0.009^{\star \star \star}$ & $-0.002^{\star \star \star}$ & $-9.31 e-6$ & $-0.006^{\star \star \star}$ & $-0.002^{\star \star \star}$ & $-2.53 e-4^{\star \star \star}$ \\
\hline North (dummy) & $0.091^{\star \star \star}$ & $0.036^{\star \star \star}$ & $0.013^{\star \star \star}$ & $0.084^{\star \star \star}$ & $0.022^{\star \star \star}$ & $9.355 e-4^{\star \star \star}$ \\
\hline Northeast (dummy) & $0.148^{\star \star \star}$ & $0.066^{\star \star \star}$ & $0.014^{\star \star \star}$ & $0.141^{\star \star \star}$ & $0.046^{\star \star \star}$ & $-0.004^{\star \star \star}$ \\
\hline Mideast (dummy) & $0.098^{\star \star \star}$ & $0.036^{\star \star \star}$ & $-0.002^{\star \star \star}$ & $0.099^{\star \star \star}$ & $0.037^{\star \star \star}$ & $-0.001^{\star \star \star}$ \\
\hline South (dummy) & $-0.069^{\star \star \star}$ & $-0.039^{\star \star \star}$ & $-0.017^{\star \star \star}$ & $-0.045^{\star \star \star}$ & $-0.019^{\star \star \star}$ & $-0.004^{\star \star \star}$ \\
\hline Constant & $12.053^{\star \star \star}$ & $13.769^{\star \star \star}$ & $15.596^{\star \star \star}$ & $11.427^{\star \star \star}$ & $13.015^{\star \star \star}$ & $15.008^{\star \star \star}$ \\
\hline
\end{tabular}

Source: FINBRA and IBGE.

\section{TABLE A2 ESTIMATED EFFECTS OF FISCAL DECENTRALIZATION ON PERSONNEL EXPENDITURES FOR BRAZILIAN LOCAL GOVERNMENTS (2000-2016)}

\begin{tabular}{|c|c|c|c|c|c|c|}
\hline \multirow{3}{*}{ Variables } & \multicolumn{6}{|c|}{ Dependent variable: personnel expenditures } \\
\hline & \multicolumn{3}{|c|}{ Tax revenue over total revenue (\%) } & \multicolumn{3}{|c|}{ Intergov. transfers per capita (In) } \\
\hline & $=0.25$ & $=0.50$ & $=0.75$ & $=0.25$ & $=0.50$ & $=0.75$ \\
\hline Fiscal decentralization & $-1.7 e-15$ & $-0.299^{\star \star \star}$ & $0.243^{\star \star \star}$ & $7.66 e-17$ & $0.178^{\star \star \star}$ & $0.193^{\star \star *}$ \\
\hline GDP (In) & $2.86 e-16$ & $0.289^{\star \star \star}$ & $0.101^{\star \star \star}$ & $1.94 \mathrm{e}-16$ & $0.208^{\star \star \star}$ & $0.032^{\star \star \star}$ \\
\hline Younger (In) & $-2.1 e-15$ & $0.029^{* * *}$ & $8.755 e-4$ & $-2.1 e-15$ & $0.138^{\star \star \star}$ & $0.115^{\star \star *}$ \\
\hline Elderly (In) & $6.28 \mathrm{e}-16$ & $0.109^{\star * *}$ & $0.050^{\star \star \star}$ & $6.18 \mathrm{e}-16$ & $0.112^{\star \star \star}$ & $0.057^{\star \star \star}$ \\
\hline Electoral cycle (dummy) & $-1.3 e-15$ & $-1.57 e-4$ & $0.004^{\star \star *}$ & $-1.3 e-15$ & $-5.51 e-5$ & $0.002^{\star \star}$ \\
\hline North (dummy) & $3.26 \mathrm{e}-14$ & 0.009 & $0.052^{\star \star \star}$ & $3.26 e-14$ & -0.017 & $0.024^{\star * \star}$ \\
\hline Northeast (dummy) & $5.38 e-16$ & $0.163^{\star \star \star}$ & $0.029^{\star \star \star}$ & $5.61 e-16$ & $0.117^{\star \star \star}$ & $-0.034^{\star \star \star}$ \\
\hline Mideast (dummy) & $2.07 e-16$ & $0.061^{\star \star \star}$ & $-0.039^{\star \star \star}$ & $2.08 e-16$ & $0.053^{\star \star \star}$ & $-0.049^{\star \star \star}$ \\
\hline South (dummy) & $-5.0 e-16$ & $-0.067^{\star \star \star}$ & $-0.048^{\star \star \star}$ & $-5.0 e-16$ & $-0.036^{\star \star \star}$ & $-0.012^{\star \star \star}$ \\
\hline Constant & $15.167^{\star \star \star}$ & $10.635^{\star \star \star}$ & $14.632^{\star * *}$ & $15.167^{\star \star \star}$ & $9.480^{\star \star \star}$ & $13.222^{\star \star \star}$ \\
\hline
\end{tabular}

Source: FINBRA and IBGE. 


\section{TABLE A3 ESTIMATED EFFECTS OF FISCAL DECENTRALIZATION ON INVESTMENT EXPENDITURES FOR BRAZILIAN LOCAL GOVERNMENTS (2000-2016)}

\begin{tabular}{|c|c|c|c|c|c|c|}
\hline \multirow{3}{*}{ Variables } & \multicolumn{6}{|c|}{ Dependent variable: investment expenditures } \\
\hline & \multicolumn{3}{|c|}{ Tax revenue over total revenue (\%) } & \multicolumn{3}{|c|}{ Intergov. transfers per capita (In) } \\
\hline & $=0.25$ & $=0.50$ & $=0.75$ & $=0.25$ & $=0.50$ & $=0.75$ \\
\hline Fiscal decentralization & $-5.7 e-15$ & $0.268^{\star \star \star}$ & $0.187^{\star \star \star}$ & $-9.5 e-15$ & $0.223^{\star \star \star}$ & $0.106^{\star \star \star}$ \\
\hline GDP (In) & $4.13 e-16$ & $0.246^{\star * *}$ & $0.050^{\star \star \star}$ & $4.03 e-15$ & $0.166^{\star \star \star}$ & $0.014^{\star \star \star}$ \\
\hline Younger (In) & $1.35 e-16$ & $0.139^{\star \star \star}$ & $0.039^{\star \star \star}$ & $-5.4 e-15$ & $0.272^{\star \star \star}$ & $0.102^{\star \star \star}$ \\
\hline Elderly (In) & $-1.9 e-15$ & $-0.034^{\star \star \star}$ & $-0.007^{\star \star \star}$ & $-2.1 e-15$ & $-0.027^{\star \star \star}$ & $-0.003^{*}$ \\
\hline Electoral cycle (dummy) & $4.57 e-15^{\star}$ & $0.041^{\star \star \star}$ & $0.006^{\star \star \star}$ & $4.68 \mathrm{e}-15^{\star}$ & $0.039^{\star \star \star}$ & $0.005^{\star \star \star}$ \\
\hline North (dummy) & $4.11 e-14$ & $-0.085^{\star \star \star}$ & $0.012^{\star \star \star}$ & $4.27 e-14$ & $-0.117^{\star \star \star}$ & $-0.003^{\star \star}$ \\
\hline Northeast (dummy) & $-2.6 e-16$ & $1.888 \mathrm{e}-4$ & $-0.004^{\star \star \star}$ & $2.84 \mathrm{e}-15$ & $-0.073^{\star \star \star}$ & $-0.04^{\star \star \star}$ \\
\hline Mideast (dummy) & $-1.2 \mathrm{e}-15$ & $0.035^{\star \star}$ & $-0.020^{\star \star \star}$ & $-8.1 e-16$ & $0.023^{*}$ & $-0.026^{\star \star \star}$ \\
\hline South (dummy) & $-8.7 e-16$ & $0.039^{\star \star *}$ & $-0.002^{* \star}$ & $-2.6 e-15$ & $0.081^{\star \star \star}$ & $0.017^{\star \star \star}$ \\
\hline Constant & $13.579^{\star \star \star *}$ & $9.651^{\star \star \star}$ & $13.792^{\star \star \star}$ & $13.579^{\star \star \star}$ & $8.026^{\star \star \star}$ & $13.005^{\star \star \star}$ \\
\hline
\end{tabular}

Source: FINBRA and IBGE.

\section{TABLE A4 ESTIMATED EFFECTS OF FISCAL DECENTRALIZATION ON LEGISLATIVE EXPENDITURES FOR BRAZILIAN LOCAL GOVERNMENTS (2000-2016)}

\begin{tabular}{|c|c|c|c|c|c|c|}
\hline \multirow[t]{3}{*}{ Variables } & \multicolumn{6}{|c|}{ Dependent variable: legislative expenditures } \\
\hline & \multicolumn{3}{|c|}{ Tax revenue over total revenue (\%) } & \multicolumn{3}{|c|}{ Intergov. transfers per capita (In) } \\
\hline & $=0.25$ & $=0.50$ & $=0.75$ & $=0.25$ & $=0.50$ & $=0.75$ \\
\hline Fiscal decentralization & $-5.2 e-15$ & -0.011 & $0.171^{\star \star \star}$ & $-3.9 e-15$ & $0.05^{\star \star \star}$ & $0.049^{\star \star \star}$ \\
\hline GDP (In) & $2.64 \mathrm{e}-16$ & $0.049^{\star \star \star}$ & $0.032^{\star \star \star}$ & $1.64 \mathrm{e}-15$ & $0.029^{\star \star \star}$ & $0.018^{\star \star \star}$ \\
\hline Younger (In) & $3.47 e-16$ & $0.004^{\star \star *}$ & $-0.007^{\star \star \star}$ & $-2.0 e-15$ & $0.034^{\star \star \star}$ & $0.021^{\star \star \star}$ \\
\hline Elderly (In) & $-8.6 e-16$ & $0.046^{\star \star \star}$ & $0.020^{\star \star \star}$ & $-9.8 e-16$ & $0.047^{\star \star \star}$ & $0.023^{\star \star \star}$ \\
\hline Electoral cycle (dummy) & $1.90 e-15$ & $-0.026^{\star \star \star}$ & $-0.007^{\star \star \star}$ & $1.97 e-15$ & $-0.026^{\star \star \star}$ & $-0.007^{\star \star \star}$ \\
\hline North (dummy) & $1.45 e-14$ & $-0.029^{\star \star \star}$ & $0.036^{\star \star \star}$ & $1.52 \mathrm{e}-14$ & $-0.037^{\star \star \star}$ & $0.029^{\star \star \star}$ \\
\hline Northeast (dummy) & $-2.8 e-16$ & -0.005 & $0.018^{\star \star \star}$ & $1.08 \mathrm{e}-15$ & $-0.019^{\star \star \star}$ & $-6.27 e-4$ \\
\hline Mideast (dummy) & $-4.7 e-16$ & $0.091^{\star \star \star}$ & $0.014^{\star \star \star}$ & $-2.6 e-16$ & $0.089^{\star \star \star}$ & $0.012^{\star \star \star}$ \\
\hline South (dummy) & $-1.2 \mathrm{e}-16$ & $-0.076^{\star \star \star}$ & $-0.011^{\star \star \star}$ & $-8.6 e-16$ & $-0.067^{\star \star \star}$ & $-0.002^{\star}$ \\
\hline Constant & $12.298^{* * *}$ & $11.436^{\star \star \star *}$ & $12.671^{\star \star \star}$ & $12.298^{\star \star \star}$ & $11.089^{\star \star \star *}$ & $12.278^{\star \star *}$ \\
\hline
\end{tabular}

Source: FINBRA and IBGE. 


\section{TABLE A5 ESTIMATED EFFECTS OF FISCAL DECENTRALIZATION ON PLANNING AND ADMINISTRATIVE EXPENDITURES FOR BRAZILIAN LOCAL GOVERNMENTS (2000-2016)}

\begin{tabular}{|c|c|c|c|c|c|c|}
\hline \multirow{3}{*}{ Variables } & \multicolumn{6}{|c|}{ Dependent variable: planning and administrative expenditures } \\
\hline & \multicolumn{3}{|c|}{ Tax revenue over total revenue (\%) } & \multicolumn{3}{|c|}{ Intergov. transfers per capita (In) } \\
\hline & $=0.25$ & $=0.50$ & $=0.75$ & $=0.25$ & $=0.50$ & $=0.75$ \\
\hline Fiscal decentralization & $1.05 e-14$ & $0.043^{\star \star \star}$ & $0.393^{\star \star \star}$ & $1.06 \mathrm{e}-14$ & $0.084^{\star \star \star}$ & $0.058^{\star \star \star}$ \\
\hline GDP (In) & $-4.5 e-16$ & $0.119^{\star \star *}$ & $0.054^{\star \star \star}$ & $-4.2 e-15$ & $0.087^{\star \star \star}$ & $0.043^{\star \star \star}$ \\
\hline Younger (In) & $-5.6 e-16$ & $-0.035^{\star \star \star}$ & $-0.017^{\star \star \star}$ & $5.69 e-15$ & $0.015^{\star \star \star}$ & $0.014^{\star \star \star}$ \\
\hline Elderly (In) & $2.01 e-15$ & $0.049^{\star \star \star}$ & $0.03^{\star \star \star}$ & $2.36 e-15$ & $0.052^{\star \star \star}$ & $0.034^{\star \star \star}$ \\
\hline Electoral cycle (dummy) & $-4.9 e-15$ & $-0.033^{\star \star \star}$ & $-0.006^{\star \star \star}$ & $-5.0 e-15$ & $-0.034^{\star \star \star}$ & $-0.007^{\star \star \star}$ \\
\hline North (dummy) & $-4.4 e-14$ & $-0.085^{\star \star \star}$ & $0.028^{\star \star \star}$ & $-4.6 e-14$ & $-0.097^{\star \star \star}$ & $0.019^{\star \star \star}$ \\
\hline Northeast (dummy) & $6.03 e-16$ & $0.021^{\star \star \star}$ & $0.021^{\star \star \star}$ & $-2.9 e-15$ & -0.004 & $-0.005^{\star \star \star}$ \\
\hline Mideast (dummy) & $1.11 \mathrm{e}-15$ & $0.090^{\star \star \star}$ & -0.002 & $5.47 e-16$ & $0.085^{\star \star \star}$ & -0.005 \\
\hline South (dummy) & $4.72 \mathrm{e}-16$ & $-0.139^{\star \star \star}$ & $-0.025^{\star \star \star}$ & $2.54 \mathrm{e}-15$ & $-0.123^{\star \star \star}$ & $-0.013^{\star \star \star}$ \\
\hline Constant & $13.746^{\star \star \star}$ & $12.248^{\star \star *}$ & $13.885^{\star \star \star}$ & $13.746^{\star \star \star}$ & $11.648^{\star \star \star}$ & $13.372^{\star \star \star}$ \\
\hline
\end{tabular}

Source: FINBRA and IBGE.

\section{TABLE A6 ESTIMATED EFFECTS OF FISCAL DECENTRALIZATION ON CULTURE AND EDUCATION EXPENDITURES FOR BRAZILIAN LOCAL GOVERNMENTS (2000-2016)}

\begin{tabular}{|c|c|c|c|c|c|c|}
\hline \multirow[t]{3}{*}{ Variables } & \multicolumn{6}{|c|}{ Dependent variable: culture and education expenditures } \\
\hline & \multicolumn{3}{|c|}{ Tax revenue over total revenue (\%) } & \multicolumn{3}{|c|}{ Intergov. transfers per capita (In) } \\
\hline & $=0.25$ & $=0.50$ & $=0.75$ & $=0.25$ & $=0.50$ & $=0.75$ \\
\hline Fiscal decentralization & $-2.6 e-15$ & $-0.141^{\star \star \star}$ & $0.271^{\star \star \star}$ & $-8.0 e-15$ & $0.149^{\star \star \star}$ & $0.156^{\star \star \star}$ \\
\hline GDP (In) & $-2.1 e-16$ & $0.109^{\star \star \star}$ & $0.062^{\star \star \star}$ & $2.89 e-15$ & $0.045^{\star \star \star}$ & $0.009^{\star \star \star}$ \\
\hline Younger (In) & $-7.7 e-16$ & $-0.023^{\star \star \star}$ & $-0.030^{\star \star \star}$ & $-5.5 e-15$ & $0.066^{\star \star \star}$ & $0.061^{\star \star \star}$ \\
\hline Elderly (In) & $-1.8 \mathrm{e}-16$ & $0.122^{\star \star \star}$ & $0.061^{\star \star \star}$ & $-4.5 e-16$ & $0.125^{\star \star \star}$ & $0.067^{\star \star \star}$ \\
\hline Electoral cycle (dummy) & $-2.1 e-15$ & $-0.025^{\star \star \star}$ & $-0.008^{\star \star \star}$ & $-2.0 e-15$ & $-0.025^{\star \star \star}$ & $-0.009^{\star \star \star}$ \\
\hline North (dummy) & $4.45 e-14$ & $-0.145^{\star \star \star}$ & $0.046^{\star \star \star}$ & $4.57 e-14$ & $-0.167^{\star \star \star}$ & $0.024^{\star \star \star}$ \\
\hline Northeast (dummy) & $-3.9 e-16$ & $0.038^{\star \star \star}$ & $0.048^{\star \star \star}$ & $2.14 \mathrm{e}-15$ & -0.003 & $-0.005^{\star \star \star}$ \\
\hline Mideast (dummy) & $-1.3 e-16$ & $0.075^{\star \star \star}$ & -0.001 & $2.27 e-16$ & $0.068^{\star \star \star}$ & $-0.010^{\star \star}$ \\
\hline South (dummy) & $-3.4 e-16$ & $-0.159^{\star \star \star}$ & $-0.036^{\star \star \star}$ & $-1.8 e-15$ & $-0.132^{\star \star \star}$ & $-0.007^{\star \star \star}$ \\
\hline Constant & $14.449^{\star \star \star}$ & $12.347^{\star \star \star}$ & $14.441^{\star \star \star}$ & $14.449^{\star \star \star}$ & $11.349^{\star \star \star *}$ & $13.279^{\star * *}$ \\
\hline
\end{tabular}

Source: FINBRA and IBGE. 


\section{TABLE A7 ESTIMATED EFFECTS OF FISCAL DECENTRALIZATION ON HEALTH EXPENDITURES FOR BRAZILIAN LOCAL GOVERNMENTS (2000-2016)}

\begin{tabular}{|c|c|c|c|c|c|c|}
\hline \multirow[t]{3}{*}{ Variables } & \multicolumn{6}{|c|}{ Dependent variable: health expenditures } \\
\hline & \multicolumn{3}{|c|}{ Tax revenue over total revenue (\%) } & \multicolumn{3}{|c|}{ Intergov. transfers per capita (In) } \\
\hline & $=0.25$ & $=0.50$ & $=0.75$ & $=0.25$ & $=0.50$ & $=0.75$ \\
\hline Fiscal decentralization & $9.12 \mathrm{e}-16$ & $-0.157^{\star \star \star}$ & $0.210^{\star \star \star}$ & $-6.6 e-15$ & $0.110^{\star \star \star}$ & $0.081^{\star \star \star}$ \\
\hline GDP (In) & $-1.1 e-15$ & $0.117^{\star \star \star}$ & $0.046^{\star \star \star}$ & $1.53 e-15$ & $0.068^{\star \star \star}$ & $0.020^{\star \star \star}$ \\
\hline Younger (In) & $8.34 \mathrm{e}-16$ & $-0.128^{\star \star \star}$ & $-0.044^{\star \star \star}$ & $-3.1 e-15$ & $-0.060^{\star \star \star}$ & 0.003 \\
\hline Elderly (In) & $-6.5 e-16$ & $0.164^{\star \star \star}$ & $0.056^{\star \star \star}$ & $-8.1 e-16$ & $0.166^{\star \star \star}$ & $0.060^{\star \star \star}$ \\
\hline Electoral cycle (dummy) & $-1.7 e-15$ & $-0.049^{\star \star \star}$ & $-0.008^{\star \star \star}$ & $-1.5 e-15$ & $-0.049^{\star \star \star}$ & $-0.009^{\star \star \star}$ \\
\hline North (dummy) & $3.44 \mathrm{e}-14$ & $0.019^{\star \star \star}$ & $0.068^{\star \star \star}$ & $3.55 e-14$ & 0.002 & $0.056^{\star \star \star}$ \\
\hline Northeast (dummy) & $-1.3 e-15$ & $0.066^{\star \star \star}$ & $0.041^{\star \star \star}$ & $6.58 \mathrm{e}-16$ & $0.036^{\star \star \star}$ & $0.012^{\star \star \star}$ \\
\hline Mideast (dummy) & $-3.9 e-16$ & $0.104^{\star \star \star}$ & $0.015^{\star \star \star}$ & $-1.0 e-16$ & $0.099^{\star \star \star}$ & $0.011^{\star \star \star}$ \\
\hline South (dummy) & $-9.3 e-17$ & $-0.107^{\star \star \star}$ & $-0.017^{\star \star \star}$ & $-1.3 e-15$ & $-0.087^{\star \star \star}$ & $-0.002^{\star \star \star}$ \\
\hline Constant & $14.139^{\star \star \star}$ & $12.642^{\star \star \star}$ & $14.524^{\star \star \star}$ & $14.139^{\star \star \star}$ & $11.917^{\star \star \star}$ & $13.899^{\star \star \star}$ \\
\hline
\end{tabular}

Source: FINBRA and IBGE.

\section{TABLE A8 ESTIMATED EFFECTS OF FISCAL DECENTRALIZATION ON SOCIAL ASSISTANCE AND SOCIAL} SECURITY EXPENDITURES FOR BRAZILIAN LOCAL GOVERNMENTS (2000-2016)

\begin{tabular}{|c|c|c|c|c|c|c|}
\hline \multirow[t]{3}{*}{ Variables } & \multicolumn{6}{|c|}{ Dependent variable: social assistance and social security expenditures } \\
\hline & \multicolumn{3}{|c|}{ Tax revenue over total revenue (\%) } & \multicolumn{3}{|c|}{ Intergov. transfers per capita (In) } \\
\hline & $=0.25$ & $=0.50$ & $=0.75$ & $=0.25$ & $=0.50$ & $=0.75$ \\
\hline Fiscal decentralization & $-3.5 e-15^{\star \star}$ & $-0.097^{\star \star \star}$ & $0.086^{\star \star \star}$ & $-1.0 \mathrm{e}-14^{\star \star}$ & $0.079^{\star \star \star}$ & $0.038^{\star \star \star}$ \\
\hline GDP $(\ln )$ & $-1.4 \mathrm{e}-15^{\star \star}$ & $0.107^{\star \star \star}$ & $0.037^{\star \star \star}$ & $2.67 e-15^{\star \star}$ & $0.072^{\star \star \star}$ & $0.024^{\star \star \star}$ \\
\hline Younger (In) & $1.25 e-15^{\star \star}$ & $-0.143^{\star \star \star}$ & $-0.038^{\star \star \star}$ & $-5.0 e-15^{\star \star}$ & $-0.095^{\star \star \star}$ & $-0.015^{\star \star \star}$ \\
\hline Elderly (In) & $-7.2 \mathrm{e}-16^{\star \star}$ & $0.162^{\star \star \star}$ & $0.045^{\star \star \star}$ & $-1.0 \mathrm{e}-15^{\star \star}$ & $0.163^{\star \star \star}$ & $0.047^{\star \star \star}$ \\
\hline Electoral cycle (dummy) & $-2.6 e-15^{\star \star}$ & $-0.018^{\star \star \star}$ & $-0.002^{\star \star \star}$ & $-2.4 \mathrm{e}-15^{\star \star}$ & $-0.018^{\star \star \star}$ & $-0.003^{\star \star \star}$ \\
\hline North (dummy) & $4.52 \mathrm{e}-14^{\star \star}$ & $0.161^{\star \star \star}$ & $0.034^{\star \star \star}$ & $4.69 \mathrm{e}-14^{\star \star}$ & $0.149^{\star \star \star}$ & $0.029^{\star \star \star}$ \\
\hline Northeast (dummy) & $-2.1 e-15^{\star \star}$ & $0.085^{\star \star \star}$ & $0.023^{\star \star \star}$ & $1.32 \mathrm{e}-15^{\star \star}$ & $0.063^{\star \star \star}$ & $0.010^{\star \star \star}$ \\
\hline Mideast (dummy) & $-4.7 e-16^{\star \star}$ & $0.150^{\star \star \star}$ & $0.011^{\star \star \star}$ & $-6.8 e-17^{\star}$ & $0.146^{\star \star \star}$ & $0.009^{\star \star \star}$ \\
\hline South (dummy) & $2.98 \mathrm{e}-17^{\star \star}$ & $-0.118^{\star \star \star}$ & $-0.024^{\star \star \star}$ & $-2.0 e-15^{\star \star}$ & $-0.103^{\star \star \star}$ & $-0.017^{\star \star \star}$ \\
\hline Constant & $12.600^{\star \star \star}$ & $11.489^{\star \star \star *}$ & $13.357^{\star \star *}$ & $12.600^{\star \star \star}$ & $10.960^{\star \star *}$ & $13.064^{\star * \star}$ \\
\hline
\end{tabular}

Source: FINBRA and IBGE. 